\title{
THE ROLE OF SINGULAR VALUES OF MEASURED FREQUENCY RESPONSE FUNCTION MATRIX IN MODAL DAMPING ESTIMATION (PART II: INVESTIGATIONS)
}

\author{
Ferenc Pápai, István Szǘcs
}

Original scientific paper

The singular value decomposition of the measured frequency response function matrix, as a very effective tool of experimental modal analysis is used over the last twenty-five years. The complex mode indication function has become a common numerical tool in processing experimental data. There are many references on the development of complex mode indication function including the enhanced mode indication function and its use together with the enhanced frequency response function to form spatial domain modal parameter estimation methods. Another amendment of the enhanced mode indicator function method is the extension of the single degree-of-freedom aspects of the complex mode indication function method to include a limited number of modes. In the paper, methods for estimation of damped eigenfrequencies, modal damping and mode shapes are presented that are based on singular value decomposition of frequency response function matrix. It is shown how to obtain phase information for the complex mode indication function, in order to use the standard single degree-of-freedom modal parameter estimation methods. New aggregated frequency response function is introduced. A leastsquares approximation will be presented for eliminating the error caused by frequency discretization. Analytical models and examples taken from vehicle industry are also used to demonstrate applications of the aggregated frequency response function method and estimation of modal damping.

Keywords: complex mode indication function; damping estimate; experimental modal analysis; frequency response function matrix; singular values decomposition

\section{Uloga singularnih vrijednosti izmjerene matrice funkcije frekventnog odziva u procjeni modalnog prigušenja (Dio Il: Istraživanja)}

Izvorni znanstveni članak Dekompozicija singularnih vrijednosti izmjerene matrice funkcije frekventnog odziva se, kao vrlo učinkovit alat eksperimentalne modalne analize, koristi zadnjih dvadeset i pet godina. Funkcija indikacije kompleksnog moda postala je uobičajeni numerički alat u obradi eksperimentalnih podataka. Veliki je broj referenci o razvoju funkcije indikacije kompleksnog moda uključujući poboljšanu funkciju indikacije moda i njenu primjenu skupa s poboljšanom funkcijom frekventnog odziva u razvoju metoda procjene modalnog parametra prostornog područja. Još jednu nadopunu poboljšanoj metodi funkcije indikatora moda predstavlja proširenje aspekata jednog stupnja slobode metode indikacije funkcije kompleksnog moda na ograničeni broj modova. U radu su predstavljene metode za procjenu prigušenih eigen frekvencija, modalnog prigušenja i oblika modova, zasnovane na dekompoziciji singularne vrijednosti matrice funkcije frekventnog odziva. Pokazano je kako dobiti faznu informaciju za funkciju indikacije kompleksnog moda u svrhu primjene standardnih metoda procjene modalnim parametrom s jednim stupnjem slobode. Uvedena je novo dobivena funkcija frekventnog odziva. Pokazat će se aproksimacija najmanjih kvadrata za eliminiranje greške izazvane diskretizacijom frekvencije. Korišteni su također analitički modeli i primjeri iz industrije vozila u svrhu demonstracije primjene dobivene metode funkcije frekventnog odziva i procjene modalnog prigušenja.

Ključne riječi: dekompozicija singularnih vrijednosti; eksperimentalna modalna analiza; funkcija indikacije kompleksnog moda; matrica funkcije frekventnog odziva; procjena prigušenja

In the Part I of this paper a new complex valued aggregator frequency response function $(a F R F)$ is introduced. The definition of the $a F R F$ function is

$$
\operatorname{aFRF}(j \omega)=e^{j \phi_{1}(\omega)} \cdot \sigma_{1}(j \omega),
$$

where $j$ is imaginary unit, $\phi_{1}(\omega)=\arg \frac{\boldsymbol{u}_{1}^{\mathrm{T}}(j \omega) \cdot \boldsymbol{u}_{1}(j \omega)}{2}$, $\sigma_{1}(j \omega)$ the first singular value of FRF matrix vs. frequency $\omega, \boldsymbol{u}_{1}(j \omega)$ the first left singular vector of FRF matrix vs. frequency $\omega$.

\section{Analytical investigations}

The properties and the applicability of the wellknown $e F R F$, the vector tracking method and the newly developed aggregated $a F R F$ have been investigated via computer simulations. A $2 \mathrm{DOF}$ and a $15 \mathrm{DOF}$ model were examined with proportional and non-proportional damping. The modal parameters (undamped eigenfrequency and modal damping) were estimated based on the $e F R F$ and $a F R F$, then they were compared to the analytical solution of the original model. The mode shapes were not the subject of this investigation. The simulations were made with MathCAD, MatLAB and LabVIEW.

\subsection{DOF analytical models}

The model used in 2DOF simulation is shown in Fig. 1.

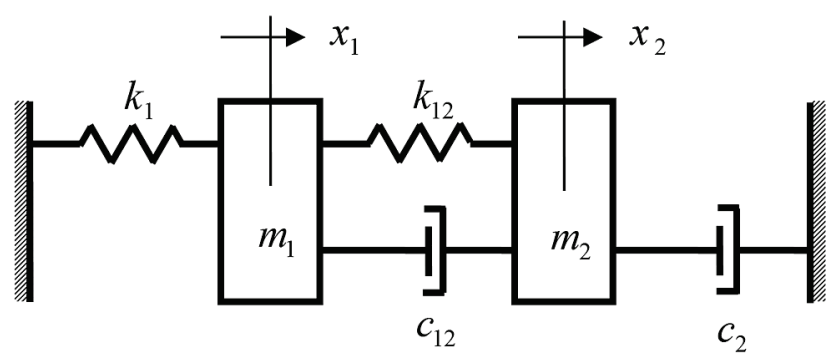

Figure $1 M D O F=2$ test model

The vector tracking method succeeded to put the left and right singular vectors in the right order when it was applied to the 2DOF model. The results of the vector tracking are shown on the bottom side of Fig. 2. The vector tracking method was able to sort the singular vectors independently of the damping model.

Parameters: $m_{1}=m_{2}=0,01 \mathrm{~kg} ; k_{1}=k_{2}=4 \mathrm{~N} / \mathrm{m}$. 
For non classical modes the damping coefficients $c_{1,2}$ $=c_{2}=0,01 \mathrm{~N} \cdot \mathrm{s} / \mathrm{m}$ should be chosen.

For classical normal mode computations let the proportional damping matrix be: $\boldsymbol{C}=\frac{0,3}{s \cdot \boldsymbol{M}}+0,01 \cdot s \cdot \boldsymbol{K}$.

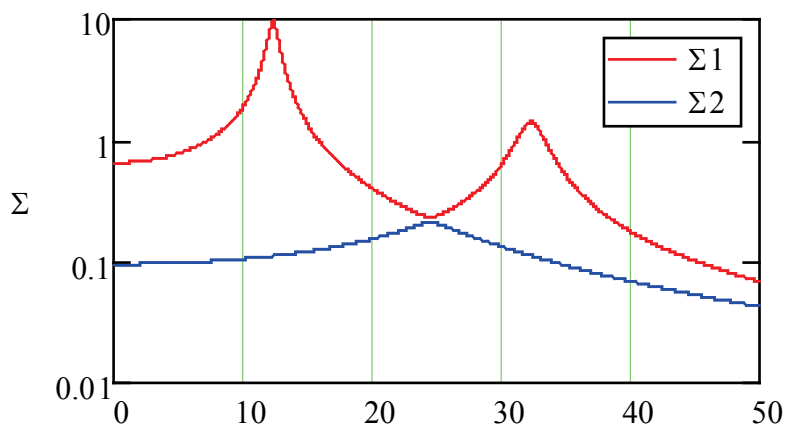

Frequency $[\mathrm{rad} / \mathrm{sec}]$

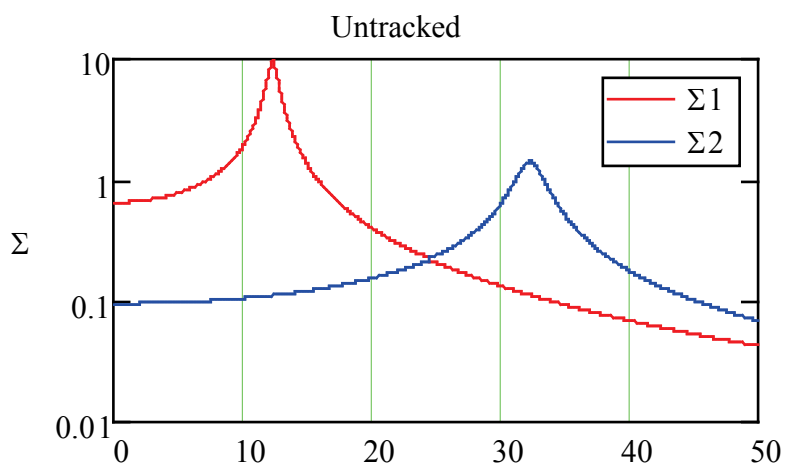

Frequency $[\mathrm{rad} / \mathrm{sec}]$

Tracked

Figure 2 Singular values of classical damped $2 D O F$ model

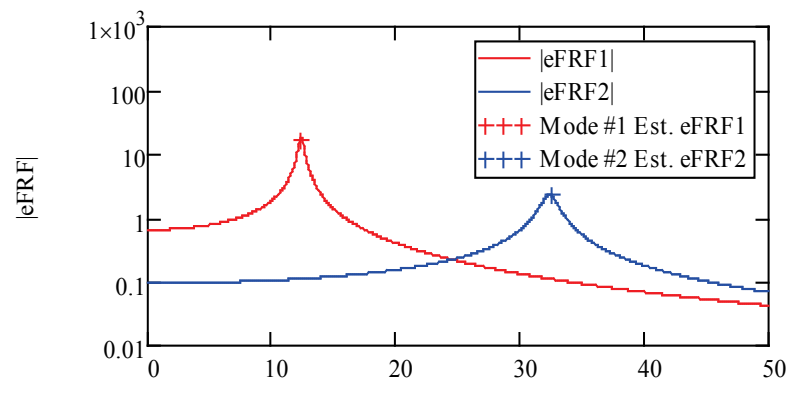

Frequency [rad/sec]

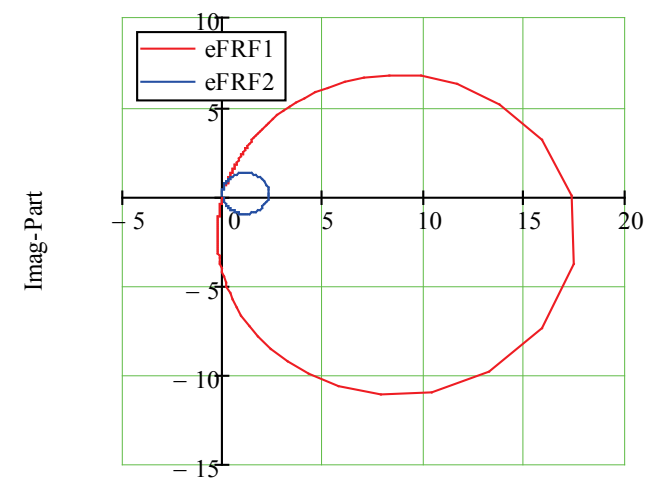

Real-P art

Figure 3 The $e F R F$ of classical damped $2 D O F$ system
The $e F R F$ diagrams of the $2 D O F$ system are drawn in Fig. 3. The least-square-method regression approximates the eigenvalues very well.

The newly developed aggregated $a F R F$ can be seen in Fig. 4. Note that this is the only global function which gives the damped eigenfrequencies at their peaks.
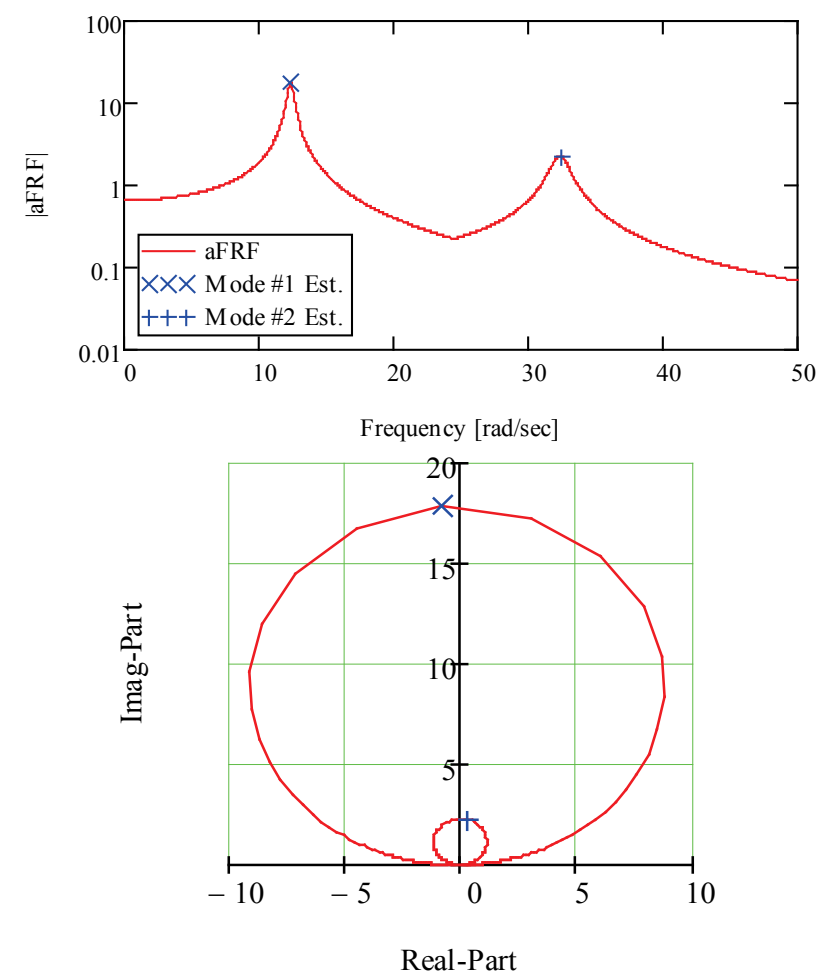

Figure 4 The $a F R F$ of classical damped $2 D O F$ system

Four points were taken from the vicinity of each peak, then the complex eigenfrequencies were calculated using the circle fitting formula detailed in Part 1 . The results can be seen in Tab. 1 and Tab. 2 .

Table 1 Classical damp. $a F R F$ estimates

\begin{tabular}{|c|c|c|}
\hline & \multicolumn{2}{|c|}{ Eigenvalues $(\mathrm{rad} / \mathrm{s})$} \\
\hline Mode & Exact & Estimated \\
\hline$\# 1$ & $-0,226+12,359 j$ & $-0,226+12,356 j$ \\
\hline$\# 2$ & $-0,674+32,354 j$ & $-0,671+32,347 j$ \\
\hline
\end{tabular}

Table 2 Non-classical damp. aFRF estimates

\begin{tabular}{|c|c|c|}
\hline & \multicolumn{2}{|c|}{ Eigenvalues $(\mathrm{rad} / \mathrm{s})$} \\
\hline Mode & Exact & Estimated \\
\hline$\# 1$ & $-0,415+12,359 j$ & $-0,414+12,352 j$ \\
\hline$\# 2$ & $-1,085+32,328 j$ & $-1,08+32,31 j$ \\
\hline
\end{tabular}

The estimation of the complex eigenvalues was eligible, the approximations are almost the same as the exact values determined from the solution of the eigenvalue problem. The effect of additional noise was not examined. This method - beyond expectations - also approximates well the modal parameters of the $2 D O F$ system with non-classical damping. Probably the reason for this is that the method does not use the left singular vector but only its phase angle.

\subsection{DOF Analytical Model}

In this section we introduce the usage and applicability of estimation methods based on the $e F R F$ 
and $a F R F$ and the use of vector tracking on a $15 D O F$ model. The structure of the $15 D O F$ model is shown in Fig. 5. Simulations were made for two typical cases:
- Classical normal modes with light damping let the damping matrix: $\boldsymbol{C}=\frac{0,01}{s \cdot \boldsymbol{M}}+1 E^{-6} \cdot s \cdot \boldsymbol{K}$

- Non-classically damped structure using parameters given in Fig. 5.

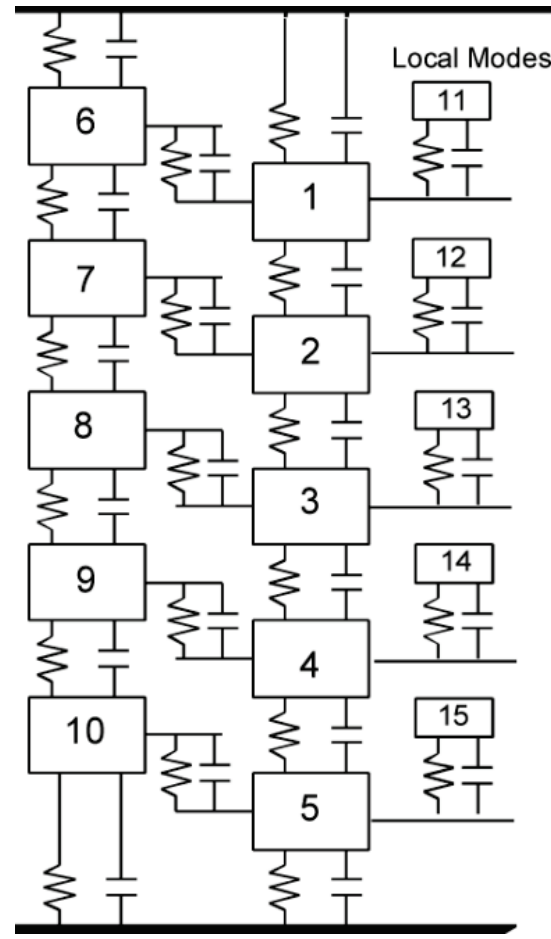

Mass in $(\mathrm{kg})$ :

$m_{1} \ldots m_{5}=0,013, m_{6} \ldots m_{10}=0,026, m_{11} \ldots m_{15}=0,001295$

Stiffness in $(\mathrm{N} / \mathrm{m})$ :

$k_{1}=1000, k_{2}=850, k_{3}=950, k_{3}=750$

$k_{0,6}=k_{1}, k_{6,1}=k_{2}, k_{0,1}=k_{3}$

$k_{6,7}=0,7 k_{1}, k_{7,2}=0,85 k_{2}, k_{1,2}=1,1 k_{3}, k_{1,11}=k_{4}$

$k_{7,8}=0,8 k_{1} \quad k_{8,3}=1,2 k_{2} \quad k_{2,3}=0,7 k_{3} \quad k_{2,12}=0,7 k_{4}$

$k_{8,9}=1,2 k_{1} \quad k_{9,4}=0,5 k_{2} \quad k_{3,4}=0,9 k_{3} k_{3,13}=1,3 k_{4}$

$k_{9,10}=0,9 k_{1} \quad k_{10,5}=1,1 k_{2} \quad k_{4,5}=1,2 k_{3} \quad k_{4,14}=0,9 k_{4}$

$k_{0,10}=1,1 k_{1} \quad k_{0,5}=0,1 k_{3} \quad k_{5,15}=1,1 k_{4}$

Figure 515DOF model

\subsubsection{Lightly-damped system with classical normal mode}

The left and right singular vectors have special structure, when $S V D$ is performed on the FRF of a system with classical normal modes. Measurement with rough frequency resolution does not provide enough points on the modal semicircle for the approximation of the modal parameters with circle fitting or the half-bandwidth method. In this example a measured $F R F$ is simulated with a particular frequency resolution, when only one measured point falls on a modal semicircle, all other measured points are outside of the half-power bandwidth. The accuracy of the approximation was examined for this case. The model of the lightly-damped structure was built using the mass and stiffness data from Fig. 5 the damping matrix was constructed as $\boldsymbol{C}=0,01 \cdot \boldsymbol{M} / s+1 E^{-6} \cdot s \cdot \boldsymbol{K}$, since we assumed proportional damping. The function of the singular values of the $F R F$ matrix of this model can be seen in Fig. 6.

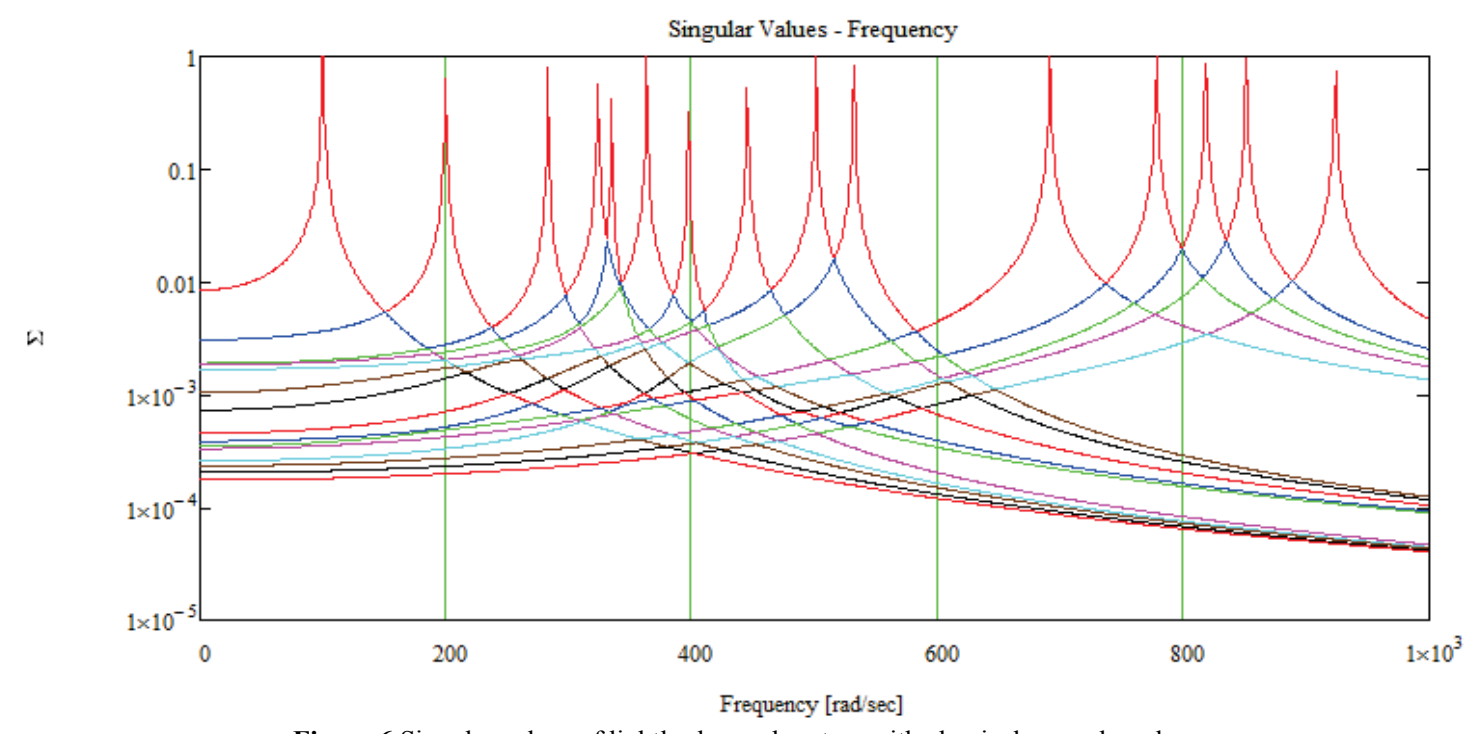

Figure 6 Singular values of lightly-damped system with classical normal modes 


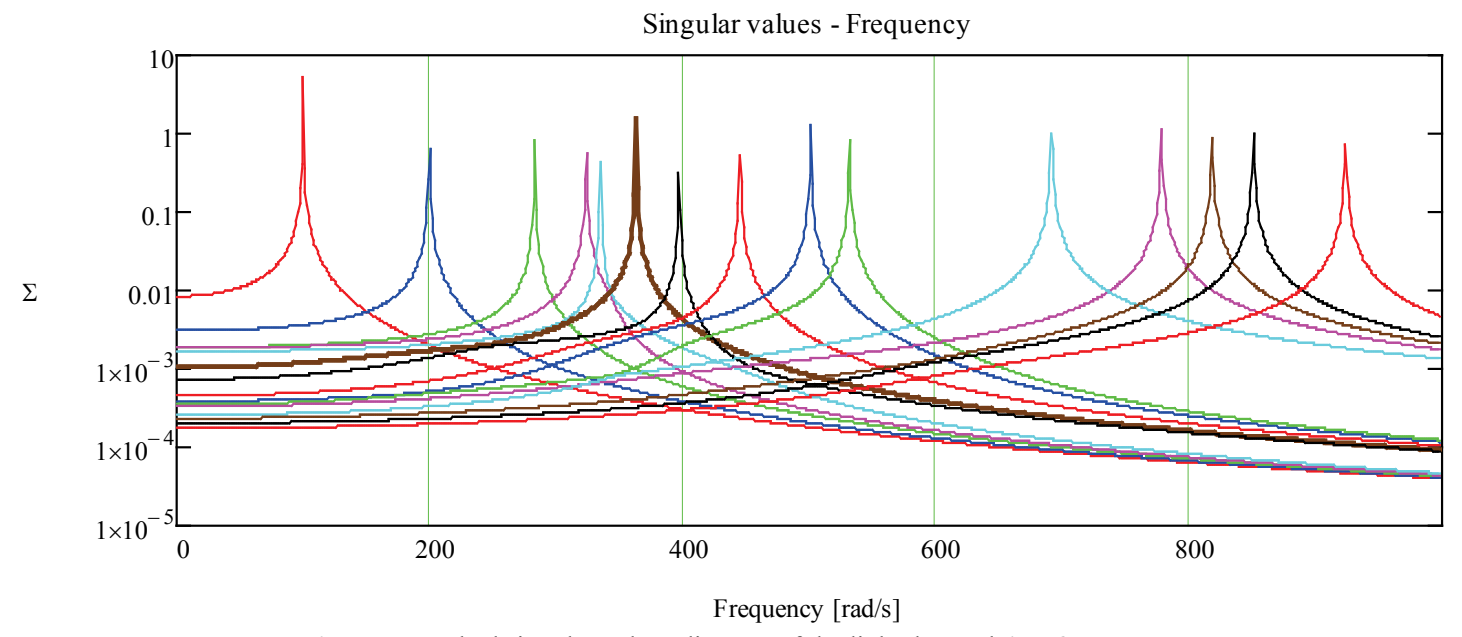

Figure 7 Tracked singular values diagram of the light damped $15 D O F$ system

Note that the curve of the first singular value (red curve) detects all eigenfrequencies of the 15 modes. Mode \#4 and mode \#5 are close eigenfrequencies. The vector tracking method described in Part I gives the ordered singular value curves, as it is shown in Fig. 7.

The vector tracking method put the singular values in the right order. It has to be noted that all the modes in this model were separated. Therefore, investigation has to be made for structures having overlapped modes. The approximations based on $e F R F$ and $a F R F$ were made for the damped eigenfrequencies of mode \#1, mode \#4 and mode \#5 (see Fig. 8).

The exact eigenfrequencies and those extracted from the $e F R F$ and $a F R F$ are compared in Tab. 3. The parameters determined with different methods show close resemblance.
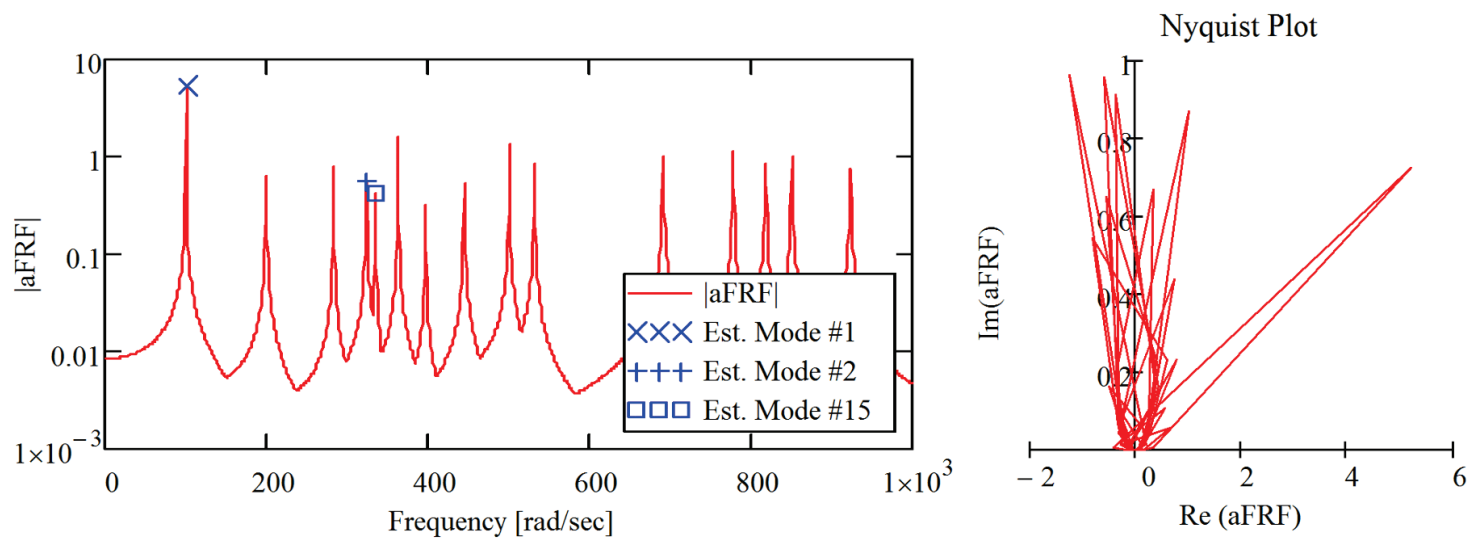

Figure 8 The $a F R F$ of the light damped 15DOF system (Left: Amplitude-frequency diagram, Right: Nyquist-Plot)

Table $3 e F R F$ and $a F R F$ estimates of light damped $15 D O F$ system

\begin{tabular}{|c|c|c|c|}
\hline & \multicolumn{3}{|c|}{ Eigenvalues (rad/s) } \\
\hline Mode & Exact & Estimation by $e F R F$ & Estimation by $a F R F$ \\
\hline$\# 1$ & $-9,993 \mathrm{E}-3+99,928 j$ & $-9,914 \mathrm{E}-3+99,929 j$ & $-9,914 \mathrm{E}-3+99,929 j$ \\
\hline$\# 4$ & $-0,057+323,689 j$ & $-0,057+323,69 j$ & $-0,057+323,69 j$ \\
\hline$\# 5$ & $-0,061+334,815 j$ & $-0,06+334,816 j$ & $-0,06+334,816 j$ \\
\hline
\end{tabular}

\subsubsection{MDOF System with General Viscous Damping}

The behavior of the $a F R F$ method has also been investigated for the case when the structure has damping matrix $\boldsymbol{C}$ that does not satisfy the $\boldsymbol{C} \boldsymbol{M}^{-1} \boldsymbol{K}=\boldsymbol{K} \boldsymbol{M}^{-1} \boldsymbol{C}$ condition, i.e. the system is generally damped. The damping coefficients $(\mathrm{Ns} / \mathrm{m})$ are:

$$
\begin{aligned}
& c_{0,6}=c_{6,7}=c_{7,8}=c_{8,9}=c_{9,10}=c_{10,0}=0,2 \\
& c_{6,1}=c_{7,2}=c_{8,3}=c_{9,4}=c_{10,5}=0,2 \\
& c_{0,1}=c_{1,2}=c_{2,3}=c_{3,4}=c_{4,5}=c_{5,0}=0,05 \\
& c_{1,11}=c_{2,12}=c_{3,13}=c_{4,14}=c_{5,15}=0,2
\end{aligned}
$$

The singular values of the $F R F$ matrix versus frequency are plotted in Fig. 9. 


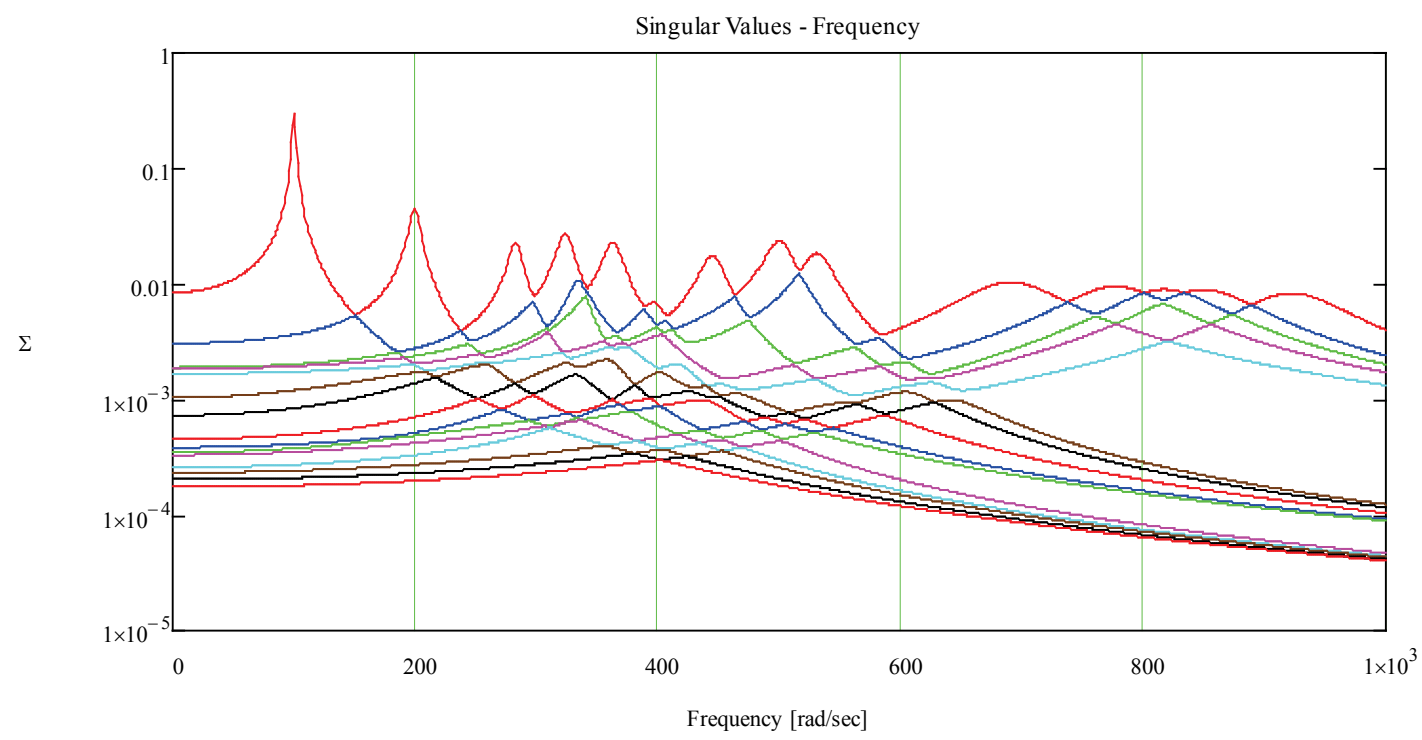

Figure 9 Non-tracked singular values of generally damped $15 D O F$ model

As it can be seen in Fig. 9, the peak which belongs to mode \#5 is not detectable on the curve of the $1^{\text {st }}$ singular value (red curve). This "lost" mode becomes visible on the plot of the $2^{\text {nd }}$ singular value (see Fig. 10).

The first singular value was used to estimate the eigenfrequency of mode $\# 1$ and mode \#4, the second singular value was used for mode \#5. The results of the approximations are in Table 4.

The extracted eigenfrequencies show close resemblance with the exact values.
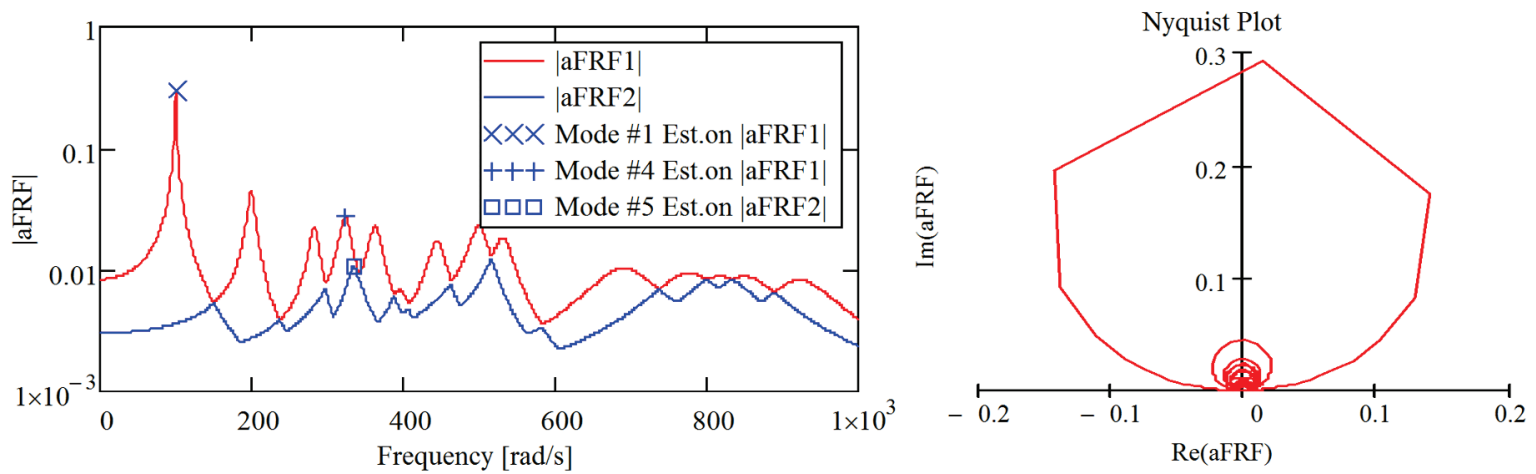

Figure 10 The $a F R F$ of the generally damped $15 D O F$ system (Left: Amplitude-frequency diagrams of $a F R F_{1}$ and $a F R F_{2}$ Right: Nyquist-Plot)

Table $4 e F R F$ and $a F R F$ estimates of generally damped $15 D O F$ system

\begin{tabular}{|c|c|c|c|}
\hline & \multicolumn{3}{|c|}{ Eigenvalues (rad/s) } \\
\hline Mode & Exact & Estimation by $e F R F$ & $-1,288 \mathrm{E}-3+99,906 j$ \\
\hline$\# 1$ & $-1,2963 \mathrm{E}-3+99,923 j$ & $-1,285 \mathrm{E}-3+99,912 j$ & $-6,588+323,503 j$ \\
\hline$\# 4$ & $-6,623+323,671 j$ & $-6,626+323,492 j$ & $-8,083+334,14 j$ \\
\hline$\# 5$ & $-8,072+334,6 j$ & Not detected & \\
\hline
\end{tabular}

\subsection{Conclusion of Analytical Experiments}

Analyzing the result of the computer simulations leads to the following statements:

- the vector tracking method has only been verified for structures having separated modes, further investigation is necessary for overlapped modes;

- $\quad$ both the $e F R F$ and $a F R F$ can be used for parameter estimation;

- the least squares approximations only use a few points on the first singular value function in the vicinity of each peak instead of using all the measured data;
- a diagram plotting all singular values has proven to be useful to detect all peaks;

- when two modes overlap, the second singular value can be used to estimate the modal parameters.

\section{Experimental Investigations}

The frequency response of a train's brake arm was measured to demonstrate the use of the $a F R F$. The brake arm and its place in the brake system can be seen in the pictures below (see Fig. 11). 

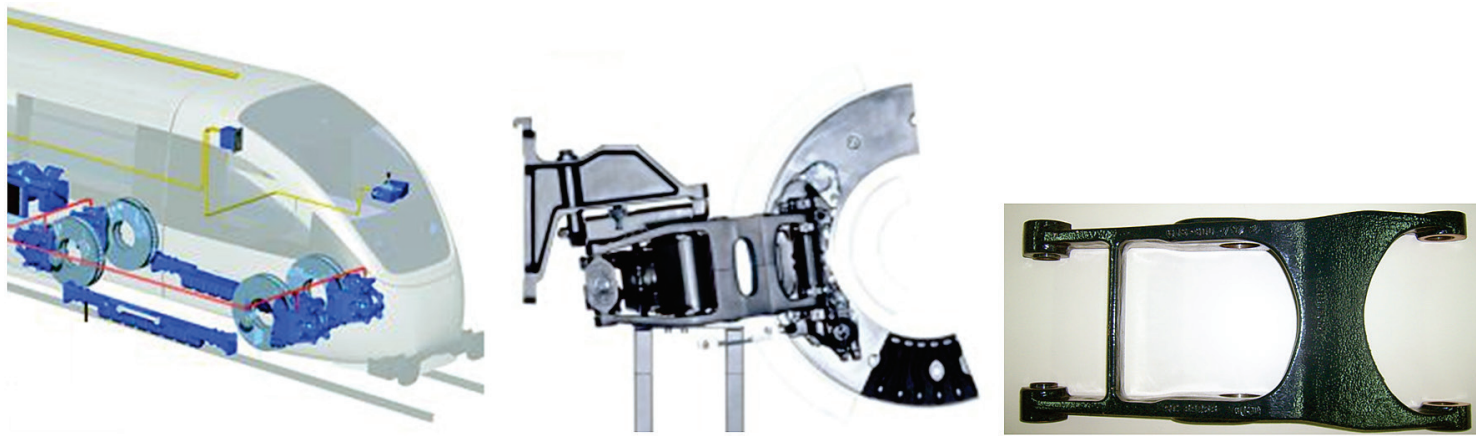

Figure 11 Location of investigated part in the brake system

(Left: Bogie equipment, Middle: Compact wheel brake caliper, Right: Brake arm www.knorr-bremse.hu

\subsection{Experimental Setup}

A total of 20 key points are selected in order to obtain full information about the dynamics of brake-arm, and their distribution is shown in Fig. 12b. Single-input single-output approach is employed during the modal test.
Each time response vibration acceleration location $1 Y$ and $2 Z$, while impacted by a hammer with force transducer is roved from point $1 \div 20$ in directions $Y$ and $Z . N_{i}=2, N_{0}=$ 40 .

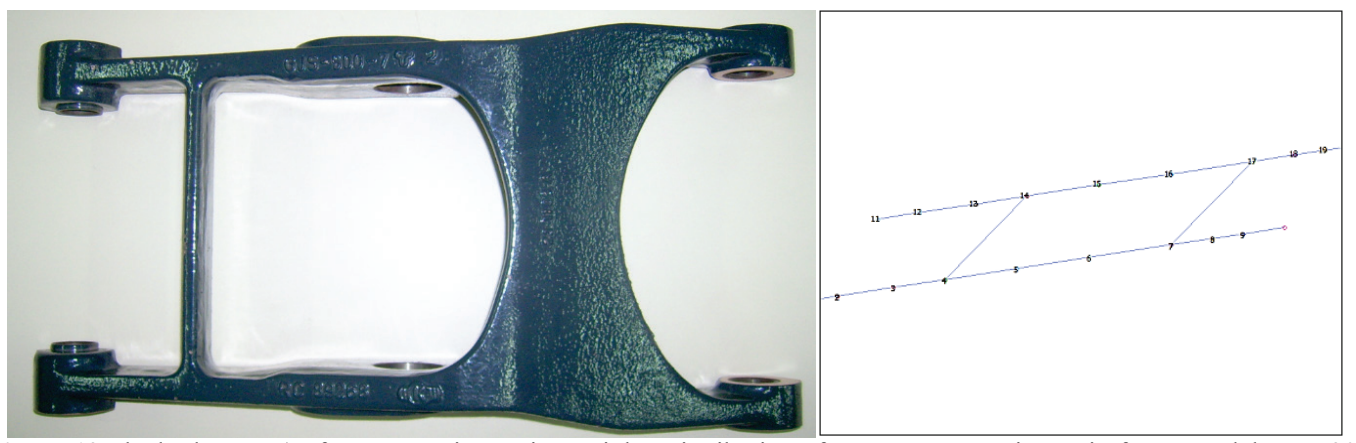

Figure 12 The brake-arm (Left: Test specimen view, Right: Distribution of measurement points, wireframe model, $\left.N_{p}=20\right)$

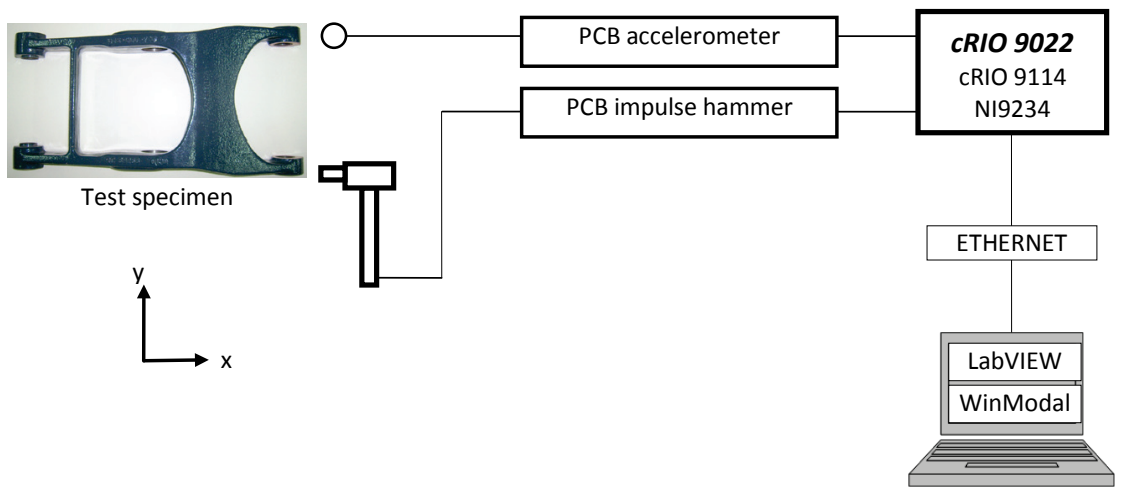

Figure 13 Schematic representation of the experimental setup of the brake-arm (EMA, SISO, FRF measurements)

The whole experimental setup includes:

- impact hammer: PCB small force hammer (086C03) Sensitivity: $2,25 \mathrm{mV} / \mathrm{g}$

- accelerometers: PCB piezo transducers

- $\quad$ signal acquisition: NI Compact RIO, FPGA module, NI9234 four-channel dynamic signal acquisition module

- analysis apparatus: ModalVIEW (LabVIEW application).

Measurements of the EMA (Experimental Modal Analysis) brake-arm, SISO (Single Input - Single Output), and FRF (Frequency Response Function) were performed (Fig. 13) and (Fig. 14). A schematic diagram of the experimental setup is shown in the illustration.

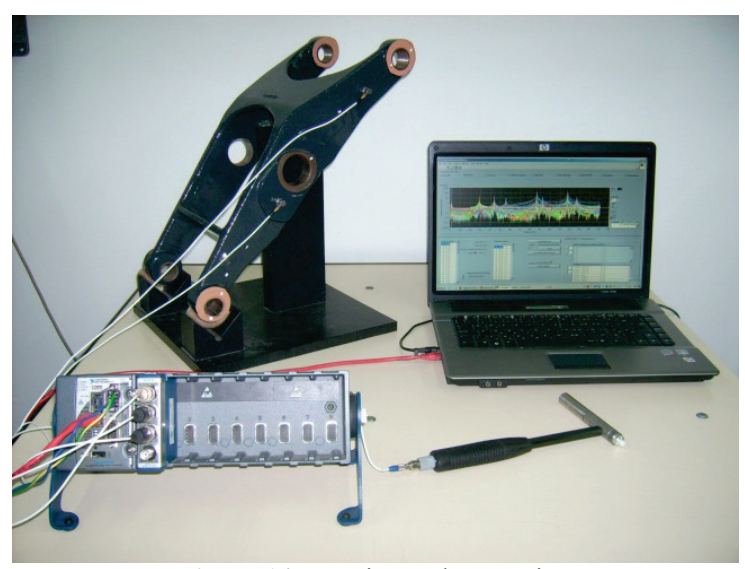

Figure 14 Experimental setup view 
The excitation and response measurements were performed horizontally $(Y)$ and vertically $(Z)$. The total number of the measured locations was 62 . Frequency range: $0 \div 1505 \mathrm{~Hz}$, frequency resolution $d f=0,04 \mathrm{~Hz}$.

\subsection{Parameter Identification}

The measured point-to-point $F R F$ are plotted on a waterfall diagram in Fig. 15. $N_{m}=7$ modes were detected Waterfal

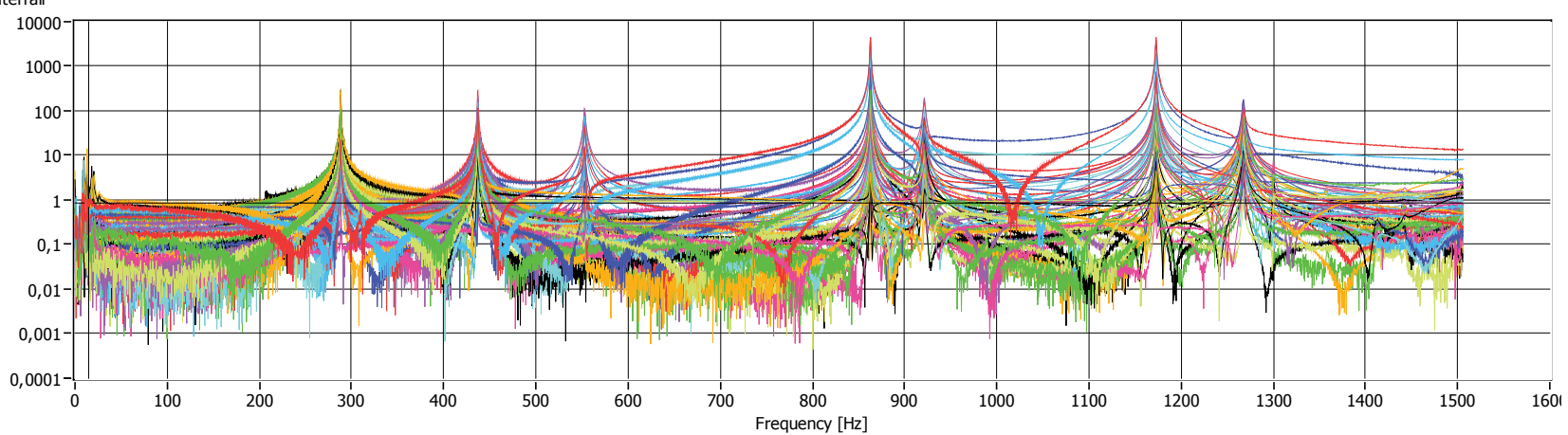

Figure 15 Waterfall diagram of 62 FRFs

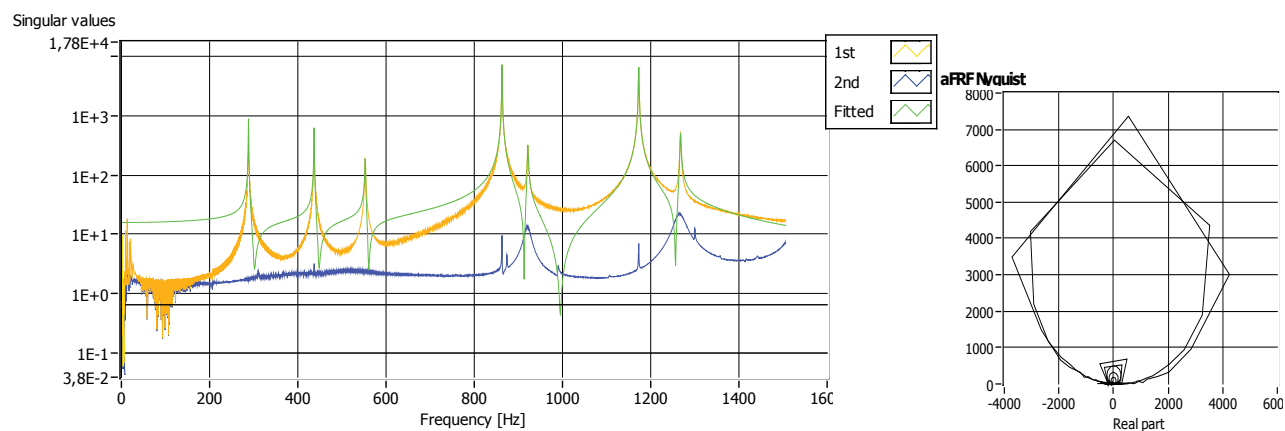

Figure 16 The $a F R F_{1}$ (yellow), $a F R F_{2}$ (blue) values and fitted $a F R F_{1}$ (green) versus frequency

By performing $S V D$ on the measured FRF the damped eigenfrequencies can easily be determined. Not every mode can be detected on every local $F R F$. For example mode\#3 cannot be detected on the $F R F$ of $2 \mathrm{Z} 1 \mathrm{Y}$ location (see Fig. 17). on the $a F R F$ in the investigated frequency range (Fig. 16). Modal damping and the damped eigenfrequency were estimated by applying the Eq. (1) formula to the $a F R F$.

Then the parameter estimations were performed by circle fitting detailed in the Part I in order to approximate the regression curve (Fig. 16). 


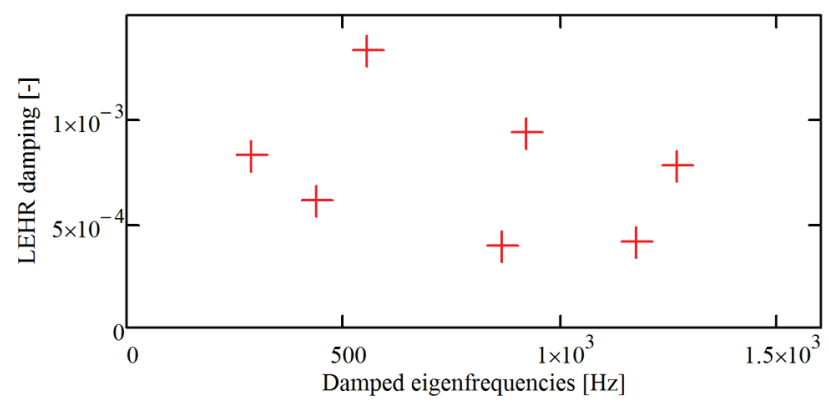

Figure 18 Estimated damping factors vs. damped eigenfrequencies

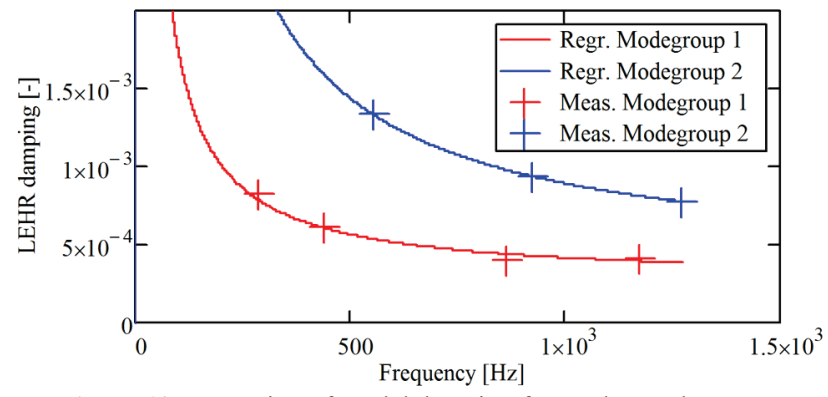

Figure 19 Regression of modal damping factors by mode groups

Note that the coefficients of these functions depend on the support of the structure. For reasons of brevity, this article does not deal with the effect of separating the structure from the support.

\section{Conclusions}

In this article the use of the singular value decomposition of the $F R F$ in order to estimate modal parameters was investigated. We found that the peaks of the singular value function estimate the damped natural frequency well. A new aggregated frequency response $a F R F$ was derived from the $e F R F$ known from the literature. The properties of the $a F R F$ function are:

- $\quad$ it is one complex function of frequency for the whole $M D O F$ system,

- each peak on the absolute value function indicates a mode, and the corresponding frequency of a peak approximates the damped natural frequency,

- this function contains phase information, thus every mode is represented as a modal circle on the Nyquist plot,

- it smoothes noise,

- the modal damping can be estimated with linear regression, not necessarily all points have to fall in the half-power bandwidth,

- also successful when only data with rough frequency resolution is provided.

\section{Acknowledgment}

The authors acknowledge the support of the "New Széchenyi Plan Új Széchenyi Terv TÁMOP-4.2.1/B09/1/KMR-2010-0002".

\section{References}

[1] Pápai, F.; Adhikai, S.; Wang B. T. Estimation of modal Dampings for Unmeasured Modes. // Slovak Journal of Civil Engineering. 20, 4(2012), pp. 17-27. DOI: 10.2478/v10189-012-0018-3

\section{Authors' addresses}

Ferenc Pápai, Assoc. Prof. PhD, Dr.

Budapest University of Technology and Economics, Faculty of Transportation Engineering and Vehicle Engineering, Department of Vehicle Elements and Vehicle-Structure Analysis H-1111 Budapest, Stoczek u. Hungary

E-mail: papai@modal.hu

István Szücs, Assoc. Prof. PhD, Dr.

University of Pécs, Pollack Mihály Faculty of Engineering and Information Technology, Department of Infrastructure and Technical Geoinformatics

H-7624 Pécs, Boszorkány u. 2. Hungary

E-mail: dr.szucsistvan@t-online.hu 